Article

\title{
Elucidating the $\mathrm{H}^{+}$Coupled $\mathrm{Zn}^{2+}$ Transport Mechanism of ZIP4; Implications in Acrodermatitis Enteropathica
}

\author{
Eitan Hoch ${ }^{\dagger} \ddagger$, Moshe Levy ${ }^{\ddagger}$, Michal Hershfinkel $@$ and Israel Sekler * \\ Department of Physiology and Cell Biology, Faculty of Health Sciences, Ben-Gurion University of the Negev, \\ Beer-Sheva 84105, Israel; eitanhoch@gmail.com (E.H.); moshe.levy3006@gmail.com (M.L.); \\ hmichal@bgu.ac.il (M.H.) \\ * Correspondence: sekler@bgu.ac.il \\ + Current address: Jnana Therapeutics, 50 Northern Avenue, Boston, MA 02210, USA. \\ $\ddagger$ These authors contributed equally to this work.
}

Received: 6 November 2019; Accepted: 14 January 2020; Published: 22 January 2020

check for updates

\begin{abstract}
Cellular $\mathrm{Zn}^{2+}$ homeostasis is tightly regulated and primarily mediated by designated $\mathrm{Zn}^{2+}$ transport proteins, namely zinc transporters (ZnTs; SLC30) that shuttle $\mathrm{Zn}^{2+}$ efflux, and ZRT-IRT-like proteins (ZIPs; SLC39) that mediate $\mathrm{Zn}^{2+}$ influx. While the functional determinants of $\mathrm{ZnT}$-mediated $\mathrm{Zn}^{2+}$ efflux are elucidated, those of ZIP transporters are lesser understood. Previous work has suggested three distinct molecular mechanisms: (I) $\mathrm{HCO}^{-}$or (II) $\mathrm{H}^{+}$coupled $\mathrm{Zn}^{2+}$ transport, or (III) a pH regulated electrodiffusional mode of transport. Here, using live-cell fluorescent imaging of $\mathrm{Zn}^{2+}$ and $\mathrm{H}^{+}$, in cells expressing ZIP4, we set out to interrogate its function. Intracellular $\mathrm{pH}$ changes or the presence of $\mathrm{HCO}^{-}$failed to induce $\mathrm{Zn}^{2+}$ influx. In contrast, extracellular acidification stimulated $\mathrm{ZIP} 4$ dependent $\mathrm{Zn}^{2+}$ uptake. Furthermore, $\mathrm{Zn}^{2+}$ uptake was coupled to enhanced $\mathrm{H}^{+}$influx in cells expressing ZIP4, thus indicating that ZIP4 is not acting as a $\mathrm{pH}$ regulated channel but rather as an $\mathrm{H}^{+}$powered $\mathrm{Zn}^{2+}$ co-transporter. We further illustrate how this functional mechanism is affected by genetic variants in SLC39A4 that in turn lead to Acrodermatitis enteropathica, a rare condition of $\mathrm{Zn}^{2+}$ deficiency.
\end{abstract}

Keywords: ZRT-IRT-like proteins, ZIP; Zinc Transporters, ZnT; zinc transport; ZIP structure function; SLC39A

\section{Introduction}

$\mathrm{Zn}^{2+}$ is an essential nutrient that plays key roles in a variety of cellular and physiological processes [1]. It is therefore not surprising that $\mathrm{Zn}^{2+}$ deficiency, underlined by an inability to acquire nutritional $\mathrm{Zn}^{2+}$, has devastating effects. These range from mental disorders, to Immune system dysfunction and growth retardation [2]. The importance of $\mathrm{Zn}^{2+}$ to human physiology is further emphasized by a recent finding that approximately 2800 proteins $(10 \%$ of the human proteome) are potentially $\mathrm{Zn}^{2+}$ binding; these include transcription factors, $\mathrm{Zn}^{2+}$ finger proteins, and a variety of enzymes [3]. Yet, little is known about the process of $\mathrm{Zn}^{2+}$ uptake and how $\mathrm{Zn}^{2+}$ ions move across membranes and into cells and organelles.

Two groups of mammalian $\mathrm{Zn}^{2+}$ transporters have been identified; SLC39 (ZIP; ZRT-IRT-like protein) mediate $\mathrm{Zn}^{2+}$ influx, and SLC30 (ZnT; Zinc transporters) mediate $\mathrm{Zn}^{2+}$ efflux [4]. The 10 members of the $\mathrm{ZnT}$ family of efflux transporters have been linked to numerous cellular processes that include insulin secretion $[5,6]$ and TNAP activation $[7,8]$. The functional mechanism of these transporters has been studied in a variety of models, from human cell cultures [9] to plants [10] and bacteria [11]; all indicating a $\mathrm{Zn}^{2+} / \mathrm{H}^{+}$exchange mechanism. The recently solved structure of a bacterial 
ZnT orthologue [12] has further enhanced our knowledge on the biochemical and biophysical properties of this group. The 14 members of the ZIP family mediate transport of $\mathrm{Zn}^{2+}$ ions into the cytoplasm, either from the extracellular surroundings of the cell, or from intracellular organelles [13]. Members of this group have been linked to various pathologies, such as Ehlers-Danlos syndrome [14,15], and cadmium toxicity [16]. In contrast to ZnTs, our understanding of the mechanisms that govern $\mathrm{Zn}^{2+}$ transport by this group is lacking. ZIPs typically have eight transmembrane domains (TMDs), with both $\mathrm{N}$ - and $\mathrm{C}$ - termini facing the extracytoplasmic side, and a histidine rich domain is found in the cytoplasmic loop between TMDs 3 and 4. The role of this loop is undetermined; however, mutating these residues in the yeast orthologue Zrt1 resulted in mislocalization of the protein, with no effect on $\mathrm{Zn}^{2+}$ transport [17]. TMDs 4 and 5 are conserved [18] and highly amphipathic, and thus have been suggested to form a cavity through which ion transport is mediated [4]. Molecular modeling of ZIP4 [19] has recently supported this, and further experimental corroboration comes from IRT1, from Arabidopsis thaliana, in which mutating charged residues in TMDs 4 and 5 reduced $\mathrm{Fe}^{2+}$ uptake, and reciprocally increased $\mathrm{Zn}^{2+}$ uptake [20]. Interestingly, mutating a charged histidine residue in the catalytic core of $\mathrm{ZnTs}$, alters $\mathrm{Zn}^{2+}$ vs. $\mathrm{Cd}^{2+}$ selectivity [21]. In the current report, we focus on ZIP4 that plays an important role in acquiring nutritional $\mathrm{Zn}^{2+}$ [22]. ZIP4 is highly expressed in the small intestines and the embryonic visceral yolk sac, where it primarily localizes to the apical plasma membrane (PM), and undergoes rapid endocytosis, following exposure to $\mathrm{Zn}^{2+}$ [23,24]. Under conditions of $\mathrm{Zn}^{2+}$ deficiency, ZIP4 is apparently cleaved and a shorter peptide of $37-40 \mathrm{kDa}$ is detected at the plasma membrane $[22,24,25]$, suggesting proteolytic processing regulates ZIP4 expression.

The importance of this transporter is emphasized in individuals with Acrodermatitis enteropathica $(\mathrm{AE})$, a rare human genetic disorder. AE is manifested by several variants of the SLC39A4 gene [26-29] that lead to $\mathrm{Zn}^{2+}$ deficiency, characterized by skin lesions, growth retardation, immune system dysfunction, and neurological disorders [2,30]. The 3D-structure of BbZIP, a prokaryotic orthologue, was recently identified and several AE-associated variants were mapped onto a ZIP4 model that was based on the solved structure. These variants are clustered around the transmembrane ZIP4 domains and are thought to be critical for ZIP4 homodimerization [31]. ZIP4 has also been signified as a marker for pancreatic cancer [32], leading to elevated $\mathrm{Zn}^{2+}$ content in tumor cells, and thus increased cell proliferation and tumor size. Reciprocally, ZIP4 down regulation had a protective effect, limiting tumor growth [33]. Despite the importance of this transporter to human health, the molecular mechanisms by which it mediates $\mathrm{Zn}^{2+}$ uptake are unknown.

Previous studies performed on mammalian members of the ZIP family suggested that $\mathrm{Zn}^{2+}$ uptake is enhanced either under alkaline conditions or following the addition of $\mathrm{HCO}^{-}$, thus suggesting a $\mathrm{Zn}^{2+} / \mathrm{HCO}^{-}$co-transport mechanism. This was suggested for ZIP2 [34], ZIP8 [35] and ZIP14 [36]. On the contrary, studies performed on FrZIP2, a close homologue to ZIP3, obtained from Takifugu rubripes (Puffer fish) have shown a reduction of $\mathrm{Zn}^{2+}$ uptake following the addition of $\mathrm{HCO}^{-}$and suggested an increase of $\mathrm{Zn}^{2+}$ uptake under acidic $\mathrm{pH}$ conditions, suggesting a possible $\mathrm{Zn}^{2+} / \mathrm{H}^{+}$co-transport mechanism [37]. A recent study mapped the catalytic core of ZIP4 suggesting a pentahedral $\mathrm{Zn}^{2+}$ coordination site composed of three histidine and two aspartate residues [38]. Furthermore, the purified and reconstituted ZIP bacterial homologue, ZIPB, acts as a $\mathrm{pH}$ regulated slow electrodiffusional channel, and not a transporter, mediating $\mathrm{Zn}^{2+}$ transport that is uncoupled from $\mathrm{HCO}^{-}$or $\mathrm{H}^{+}$transport [39]. Here we monitor cytoplasmic $\mathrm{Zn}^{2+}$ and $\mathrm{pH}$ changes in HEK293-T cells. Our results indicate that in contrast to the channel-like behavior of the bacterial transporter, the ZIP4-mediated transport of $\mathrm{Zn}^{2+}$ and $\mathrm{H}^{+}$is coupled, supporting a $\mathrm{Zn}^{2+} / \mathrm{H}^{+}$co-transport mode. This suggests that $\mathrm{ZIP} 4$ has undergone an evolutionary transformation from a channel to a transporter. We further study how ion transport is affected by two SLC39A4 genetic variants associated with $\mathrm{Zn}^{2+}$ deficiency in AE patients. 


\section{Results}

\section{1. $\mathrm{Zn}^{2+}$ Transport by ZIP4}

Previous studies have shown that ZIP4, as well as other members of the ZIP family, undergoes rapid endocytosis in the presence of extracellular $\mathrm{Zn}^{2+}[23,24]$, thus constituting a major experimental challenge in directly monitoring the transport mechanism of ZIP4. Therefore, we initially asked if the rates of transport and endocytosis are sufficiently different to distinguish between. The rate of endocytosis was monitored using the well-established ZIP4 surface-labeling protocol, in which the cells express mZIP4 tagged at its c-terminal with a hemagglutinin (HA) tag facing the extracellular side [23]. $\mathrm{Zn}^{2+}(50 \mu \mathrm{M})$ was added to HEK293-T cells expressing HA-tagged mZIP4 as indicated (Figure 1A). Cells were then washed with ice-cold PBS, and immediately transferred to ice, in order to stop any endocytosis. Subsequently, intact cells were fixed but not permeabilized in PFA and exposed to anti-HA antibodies that thus recognized only the surface bound mZIP4 [23]. Unbound antibodies were extensively washed and level of bound HA, representing surface ZIP4 expression, was determined as a function of exposure time by WB analysis with secondary antibodies to mark the bound anti-HA antibody. Consistent with pervious results [23], no internalization of ZIP4 was observed during the first $2 \mathrm{~min}$ of $\mathrm{Zn}^{2+}$ exposure (Figure 1A) and a reduction in ZIP4 surface expression was only monitored after $5 \mathrm{~min}$. Our ensuing transport assays were therefore set to a 2-min time interval, following the addition of $\mathrm{Zn}^{2+}$, thus allowing accurate monitoring of $\mathrm{Zn}^{2+}$ transport, uninterrupted by ZIP4 endocytosis.

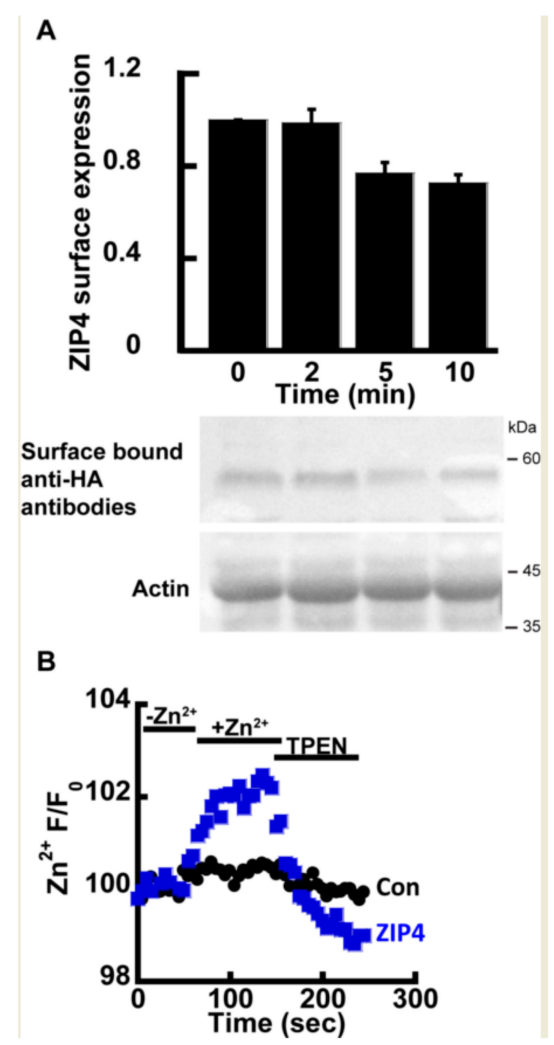

Figure 1. $\mathrm{ZIP} 4 \mathrm{Zn}^{2+}$ transport assay. (A) Immunoblot analysis (Lower panel) and normalized surface expression by densitometry (upper panel) of HEK293-T cells transfected with hemagglutinin (HA)-tagged mZIP4 and exposed to $20 \mu \mathrm{M} \mathrm{Zn}^{2+}$ for the indicated times $N \geq 5$. (B) Experimental assay used to monitor $\mathrm{Zn}^{2+}$ uptake in HEK293-T cells transfected with an empty control vector (black) or

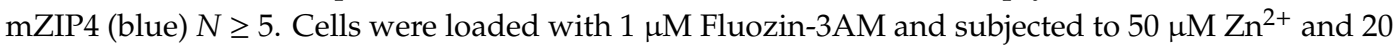
$\mu \mathrm{M}$ TPEN, as indicated. 
$\mathrm{Zn}^{2+}$ transport by ZIP4 was monitored in HEK293-T overexpressing mZIP4 or control cells transfected with the empty pcDNA3.1 (empty vector, used as control also in all subsequent experiments) and preloaded with $1 \mu \mathrm{M}$ Fluozin-3AM, a $\mathrm{Zn}^{2+}$ sensitive fluorescent probe, commonly used for monitoring $\mathrm{Zn}^{2+}$ transport [21,40]. Cells were perfused in Ringer's solution containing $50 \mu \mathrm{M} \mathrm{Zn^{2+ }}$ and the rate of $\mathrm{Zn}^{2+}$ transport was measured and compared to cells transfected with a control vector. $\mathrm{Zn}^{2+}$ transport rates mediated by ZIP4 expressing cells were strongly enhanced compared control cells transfected with an empty vector (Figure 1B), indicating that the expression of ZIP4 is linked to enhanced $\mathrm{Zn}^{2+}$ transport. To ascertain the increase in Fluozin-3AM fluorescence is triggered by cytoplasmic $\mathrm{Zn}^{2+}$, the $\mathrm{Zn}^{2+}$ sensitive intracellular chelator TPEN was added at the end of the experiment, following which cytoplasmic fluorescence returned to baseline levels, thus indicating that the fluorescent signal is mediated by changes in cytosolic $\mathrm{Zn}^{2+}$. Altogether the results of this part indicate that expression of ZIP4 leads to enhanced $\mathrm{Zn}^{2+}$ influx across the PM.

\section{2. $\mathrm{Zn}^{2+}$ Uptake by ZIP4 is $\mathrm{pH}$ Dependent}

We next sought to determine the mechanism that drives $\mathrm{Zn}^{2+}$ transport by ZIP4. In other members of the ZIP family, $\mathrm{Zn}^{2+}$ transport was suggested to be coupled to $\mathrm{HCO}^{-}$[34-36], and we therefore sought to determine the effect of $\mathrm{HCO}^{-}$on $\mathrm{Zn}^{2+}$ transport mediated by ZIP4. To address this, HEK293-T cells were transfected with either ZIP4 or an empty control vector, and $\mathrm{Zn}^{2+}$ transport was compared in cells perfused with pH7.4 Ringer's solution containing $50 \mu \mathrm{M} \mathrm{Zn}^{2+}$, in the presence or absence of $20 \mathrm{mM} \mathrm{NaHCO} 3$ (Figure 2A). No significant differences were observed, and our results, therefore, did not support a $\mathrm{Zn}^{2+} / \mathrm{HCO}^{-}$coupled transport mechanism for ZIP4.

Studies performed on ZIP homologues from other species, such as the bacterial ZIPB [39] and puffer fish FrZIP2 [37], suggest ZIPs act as $\mathrm{H}^{+}$activated $\mathrm{Zn}^{2+}$ channels that are independent of $\mathrm{HCO}^{-}$. To determine the effect of $\mathrm{pH}$ on $\mathrm{Zn}^{2+}$ transport, by $\mathrm{ZIP} 4$, we monitored $\mathrm{Zn}^{2+}$ transport at the indicated $\mathrm{pH}$ values (Figure $2 \mathrm{~B}$ ). $\mathrm{Zn}^{2+}$ transport shows strong $\mathrm{pH}$ dependency, with a four-fold increase of ZIP4 mediated $\mathrm{Zn}^{2+}$ transport rates at $\mathrm{pH} 5$ compared to $\mathrm{pH} 7.4$ (Figure 2C). In contrast, no increase in $\mathrm{Zn}^{2+}$ transport was monitored in control cells, expressing an empty vector, at $\mathrm{pH} 5$, when compared to $\mathrm{pH} 7.4$, indicating that this $\mathrm{pH}$ effect is related to ZIP4 activity and not to a non-selective $\mathrm{pH}$ dependent change in $\mathrm{Zn}^{2+}$ concentrations that may occur by cytosolic acidification [41]. Sensitivity of $\mathrm{Zn}^{2+}$ transport to $\mathrm{pH}$ was similar to that documented for the bacterial and puffer fish homologues $[37,39]$. The rates were fitted using a Michaelis-Menten curve and the Hill's coefficient was $5.1 \pm 0.8$, indicating a $\mathrm{Zn}^{2+} / \mathrm{H}^{+}$ stoichiometry of 1:5.

To determine if $\mathrm{pH}$ controls the apparent affinity or maximal rate of $\mathrm{ZIP} 4$ mediated $\mathrm{Zn}^{2+}$ transport, we also conducted a $\mathrm{Zn}^{2+}$ dose-response analysis at $\mathrm{pH} 5$ and $\mathrm{pH}$ 7.4. Utilizing the same experimental design described previously, we monitored rates of $\mathrm{Zn}^{2+}$ influx at various $\mathrm{Zn}^{2+}$ concentrations ranging from 0-800 $\mu \mathrm{M}$ (Figure 2D). The results were fitted to a Michaelis-Menten equation that suggested that the affinity for $\mathrm{Zn}^{2+}$ transport $(\mathrm{Km})$ was $\mathrm{pH}$ independent, but the rate of ion transport (Vmax) doubled from 0.5 at $\mathrm{pH} 7.4$ to $1.1 \mathrm{~s}^{-1}$ at $\mathrm{pH} 5$, indicating that acidic $\mathrm{pH}$ accelerates the turnover rate of $\mathrm{Zn}^{2+}$ transport, with no effect on affinity.

Acidic extracellular $\mathrm{pH}$ will lead to an intracellular $\mathrm{pH}$ drop. The latter can in turn trigger an intracellular $\mathrm{Zn}^{2+}$ rise that is independent of ZIP4 activity, by enhancing the dissociation of intracellular bound $\mathrm{Zn}^{2+}[40,41]$. In such conditions, the observed increase in $\mathrm{Zn}^{2+}$ accumulation rates may not necessarily be through an extracellular effect on mZIP4, but by a change in cytosolic $\mathrm{pH}$. To address this possibility, we applied the well documented ammonium pre-pulse paradigm [42] that selectively triggers an intracellular, but not extracellular, $\mathrm{pH}$ change, in cells preloaded with either $1 \mu \mathrm{M}$ BCECF-AM (Figure 3A) or $1 \mu \mathrm{M}$ Fluozin-3AM (Figure 3B). All solutions were $\mathrm{Na}^{+}$free, to prevent the activation of $\mathrm{H}^{+}$efflux via the major cytosolic acid extruder, the $\mathrm{Na}^{+} / \mathrm{H}^{+}$exchanger. Following intracellular acidification, $50 \mu \mathrm{M} \mathrm{Zn}^{2+}$ were added and both $\mathrm{Zn}^{2+}$ and $\mathrm{H}^{+}$transport rates were compared in Zip4 or control cells (Figure 3C). No significant differences were observed indicating the $\mathrm{pH}$ activation of $\mathrm{Zn}^{2+}$ transport relies solely on extracellular protons. Furthermore, intracellular 
acidification triggered an inhibition of $\mathrm{Zn}^{2+}$ transport by ZIP4 indicating that the reversal of the $\mathrm{H}^{+}$ gradient potentially blocked $\mathrm{Zn}^{2+}$ transport. Note that a similar result was obtained with FrZIP2, in which $\mathrm{Zn}^{2+}$ transport was inhibited following the addition of extracellular $\mathrm{HCO}^{-}$[37].

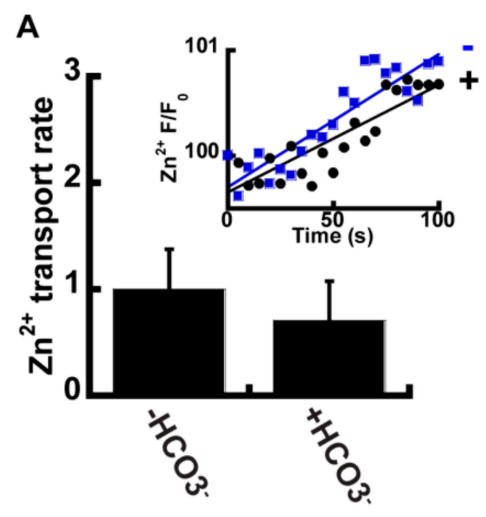

C

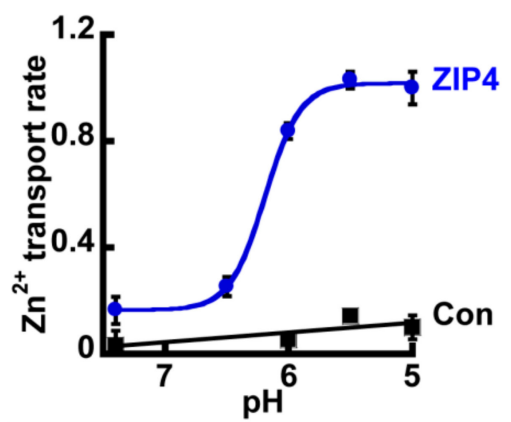

B

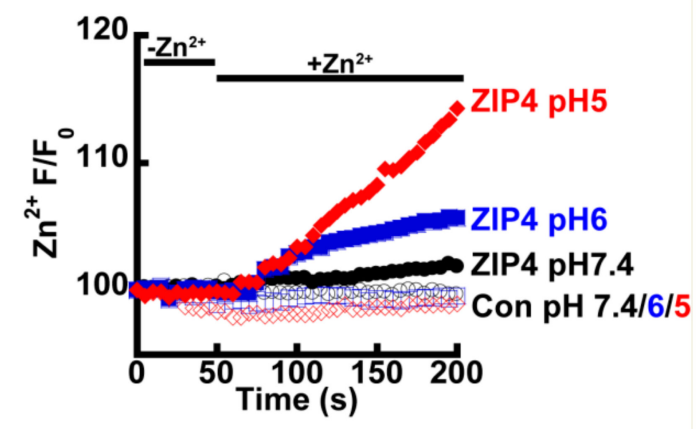

D

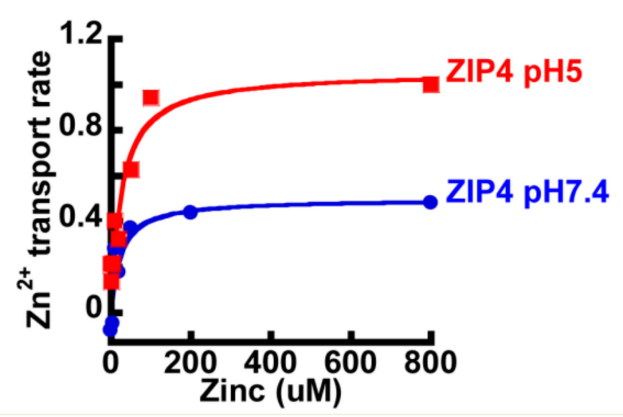

Figure 2. ZIP4-mediated $\mathrm{Zn}^{2+}$ transport is $\mathrm{pH}$ dependent. (A) $\mathrm{HCO}^{-}$has no effect on $\mathrm{Zn}^{2+}$ uptake. HEK293-T cells transfected with ZIP4 were loaded with $1 \mu \mathrm{M}$ Fluozin-3AM and loaded with $50 \mu \mathrm{M}$ $\mathrm{Zn}^{2+}$ in HEPES buffered Ringer's solution (blue, in inset) or $20 \mathrm{mM} \mathrm{NaHCO}{ }^{-}$buffered Ringer's solution (black, in inset) $N \geq 3$. Normalized $\mathrm{Zn}^{2+}$ uptake rates in the presence or absence of $\mathrm{HCO}^{-}$ and is shown in the bar graph. (B) Representative traces of $\mathrm{Zn}^{2+}$ uptake, in HEK293-T cells, transfected with an empty control vector (empty symbols) or mZIP4 (full symbols) that were applied in Ringer's solution at different $\mathrm{pH}$ levels, as indicated. (C) Normalized rates of $\mathrm{Zn}^{2+}$ uptake (compared to the rate of transport by mZIP4 at pH 5) by cells expressing either mZIP4 or a control vector $N \geq 5$. Curve is a Michaelis Menten fit. (D) Rates of $\mathrm{Zn}^{2+}$ uptake, in HEK293-T cells expressing ZIP4, at pH 7.4 (blue) and $\mathrm{pH} 5$ (red), at the indicated $\mathrm{zn}^{2+}$ concentrations $(0-800 \mu \mathrm{M})$. Curve is a Michaelis Menten fit $N \geq 4$. 


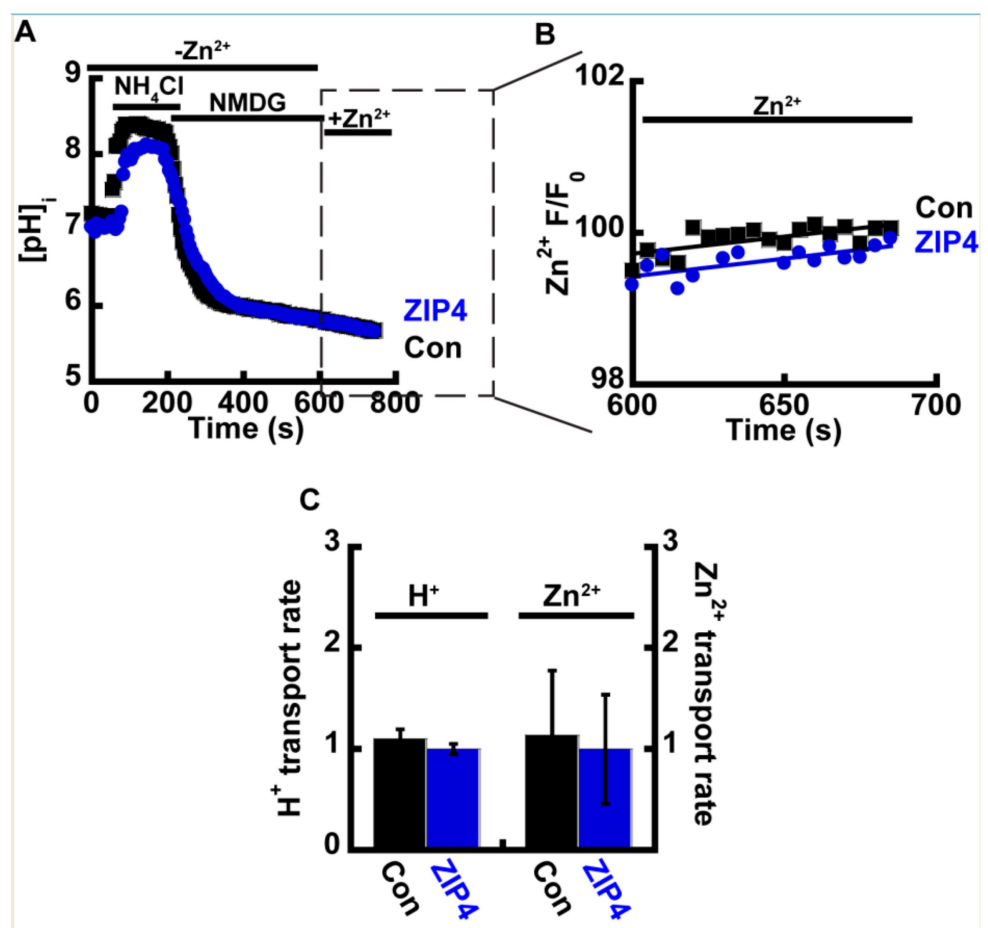

Figure 3. Intracellular acidification limits $\mathrm{Zn}^{2+}$ uptake. (A) Representative traces of HEK293-T cells transfected with ZIP4 (blue) or an empty control vector (black), loaded with $1 \mu \mathrm{M}$ BCECF-AM, and subjected to ammonium pre-pulse paradigm to monitor cytoplasmic $\mathrm{pH}$ changes without extracellular acidification. (B) Corresponding $\mathrm{Zn}^{2+}$ traces in cells loaded with $1 \mu \mathrm{M}$ Fluozin-3AM. Note that traces are presented only upon the addition of $\mathrm{Zn}^{2+}$, following acidification. (C) Normalized $\mathrm{H}^{+}$ and $\mathrm{Zn}^{2+}$ transport rates $\mathrm{N} \geq 4$.

\section{3. $\mathrm{Zn}^{2+}$ and $\mathrm{H}^{+}$Transport by ZIP4 Are Coupled}

The above results strengthen the hypothesis that extracellular $\mathrm{H}^{+}$ions generate the driving force for ZIP4, suggesting two possible modes of transport for ZIP4: (1) $\mathrm{H}^{+} / \mathrm{Zn}^{2+}$ co-transporter and (2) $\mathrm{H}^{+}$ sensitive $\mathrm{Zn}^{2+}$ channel. To distinguish between these modes of operation, $\mathrm{H}^{+}$transport was monitored in ZIP4 expressing cells preloaded with $1 \mu \mathrm{M}$ BCECF-AM. We reasoned that if ZIP4 acts as a channel, no ZIP4 mediated proton transport would be observed.

At $\mathrm{pH} 7.4$, no differences were observed in intracellular $\mathrm{pH}$ in the presence of $\mathrm{Zn}^{2+}$ (Figure 4A), however at $\mathrm{pH} 5$, a clear rise in cellular acidification was observed in ZIP4 expressing cells, when compared to control cells (Figure 4A,B). This effect is illustrated in Figure 4C that compares the rates of $\mathrm{Zn}^{2+}$ transport and $\mathrm{pH}$ changes in cells expressing ZIP4, at pH 7.4 (left panel) vs. pH 5 (right panel). Note the strong reciprocity between cytosolic $\mathrm{pH}$ acidification and $\mathrm{Zn}^{2+}$ influx, which were both enhanced at acidic $\mathrm{pH}$. Altogether our results suggest that ZIP4 mediates $\mathrm{H}^{+} / \mathrm{Zn}^{2+}$ co-transport. Under neutral $\mathrm{pH}$ conditions, both $\mathrm{Zn}^{2+}$ and $\mathrm{H}^{+}$fluxes were subtle. In an acidic extracellular environment, $\mathrm{Zn}^{2+}$ and $\mathrm{H}^{+}$influx rates were strongly increased, supporting an $\mathrm{H}^{+} / \mathrm{Zn}^{2+}$ co-transport mechanism (Figure 4D). 


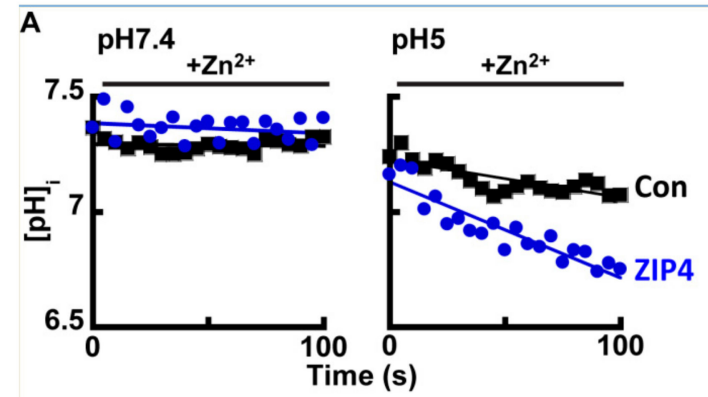

C

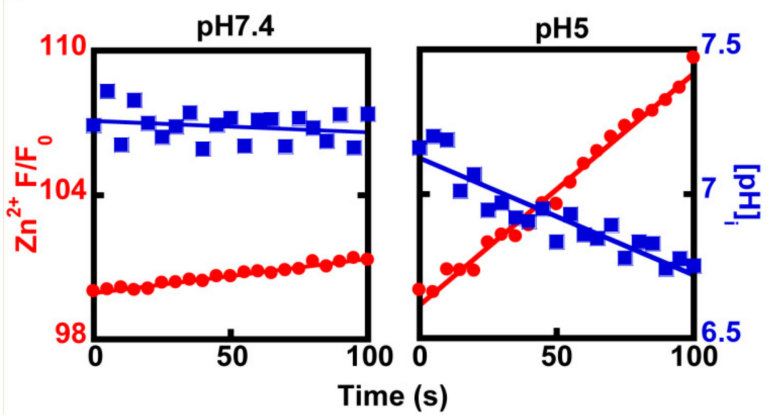

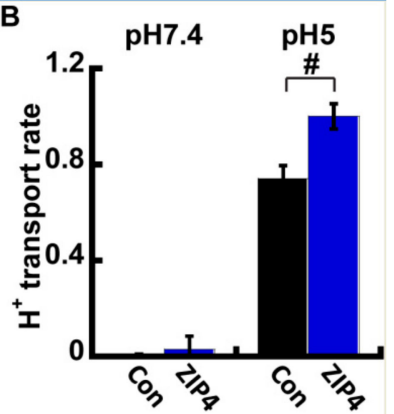

D

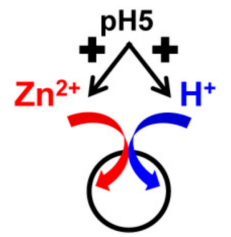

Figure 4. ZIP4 mediates $\mathrm{H}^{+}$coupled $\mathrm{Zn}^{2+}$ transport. (A) Representative traces of HEK293-T cells transfected with ZIP4 (blue) or a control vector (black), loaded with $1 \mu \mathrm{M}$ BCECF-AM, and monitored for cytoplasmic $\mathrm{pH}$ changes at $\mathrm{pH} 7.4$ (left) or $\mathrm{pH} 5$ (right), following the addition of $50 \mu \mathrm{M} \mathrm{Zn}^{2+}$. (B) Normalized $\mathrm{H}^{+}$transport rates recorded from control (black) or ZIP4 (blue) expressing cells, in the presence of $50 \mu \mathrm{M} \mathrm{Zn}{ }^{2+}$ in the extracellular solution $N \geq 5$. (C) Representative traces of $\mathrm{Zn}^{2+}$ (red) and $\mathrm{H}^{+}$transport (blue), recorded with Fluozin-3AM and BCECF-AM accordingly. Note that $\mathrm{H}^{+}$uptake is parallel to $\mathrm{Zn}^{2+}$ uptake. (D) Illustration of the suggested mechanisms of ZIP4. In (B), \# is $p \leq 0.05$ between control cells and cells expressing ZIP4 at pH 5 .

\subsection{Acrodermatitis Enteropathica Associated Variants Disrupt $\mathrm{Zn}^{2+}$ Transport by ZIP4}

Genetic variants in SLC39A4 are linked to $\mathrm{Zn}^{2+}$ deficiency in humans [26-29], but zinc supplementation has not always proven a useful treatment, implying different molecular mechanisms originating from different variants. Several SLC39A4 coding variants were previously tested and displayed varying levels of expression, as well as varying levels of $\mathrm{Zn}^{2+}$ uptake [29]. We focused on two variants of the SLC39A4 gene, for which surface expression was previously reported [29] and reproduced in our hands (Figure 5A). The P200L variant is a mutation of a residue situated at the cytoplasmic N-terminus domain, and G539R is a residue within the loop connecting TMDs 4 and 5 that form the catalytic site (Figure $5 \mathrm{~B}$ ). $\mathrm{Zn}^{2+}$ and $\mathrm{H}^{+}$transport, mediated by $\mathrm{ZIP} 4{ }^{\mathrm{P} 200 \mathrm{~L}}$ were no different from those of the wild type ZIP4 (Figure 5C-E), suggesting that the P200L variant is not catalytically linked to the transport activity of ZIP4. Thus, $\mathrm{Zn}^{2+}$ deficiency observed in patients harboring this variant may be linked to other processes, e.g., cell surface dynamics of this transporter. $\mathrm{Zn}^{2+}$ transport by $\mathrm{ZIP} 4{ }^{\mathrm{G} 539 \mathrm{R}}$, on the other hand, was not activated at acidic $\mathrm{pH}$ conditions and maintained basal activity at both $\mathrm{pH} 7.4$ and $\mathrm{pH} 5$ (Figure $5 \mathrm{C}, \mathrm{D}, \mathrm{F}$ ), suggesting a role for this residue in $\mathrm{pH}$ activation of ZIP4. A prediction for such a role is that $\mathrm{H}^{+}$transport will also be affected. When assayed for $\mathrm{H}^{+}$ transport, cells expressing ZIP4 ${ }^{\mathrm{G} 539 \mathrm{R}}$ demonstrated diminished $\mathrm{H}^{+}$transport at $\mathrm{pH} 5$, supporting a role of this residue in $\mathrm{pH}$ activation of the transporter, possibly due to its proximity to the catalytic core formed by TMDs 4 and 5. Thus, the reduction in both $\mathrm{Zn}^{2+}$ and $\mathrm{H}^{+}$transport mediated by $\mathrm{ZIP} 4{ }^{\mathrm{G} 539 \mathrm{R}}$ suggests that the substitution of the small non-charged glycine to a larger charged arginine, encountered in AE patients, disrupts the coupling of the $\mathrm{H}^{+}$driving force and $\mathrm{Zn}^{2+}$ transport. 
A

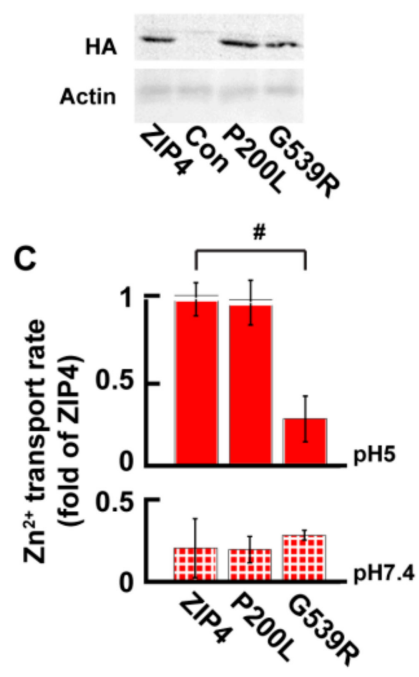

D

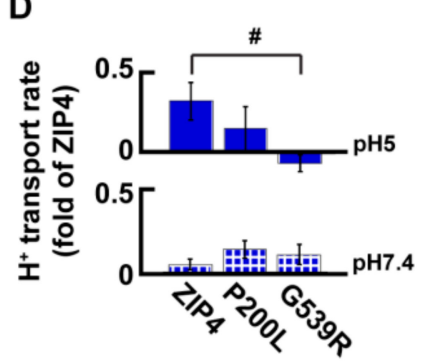

B

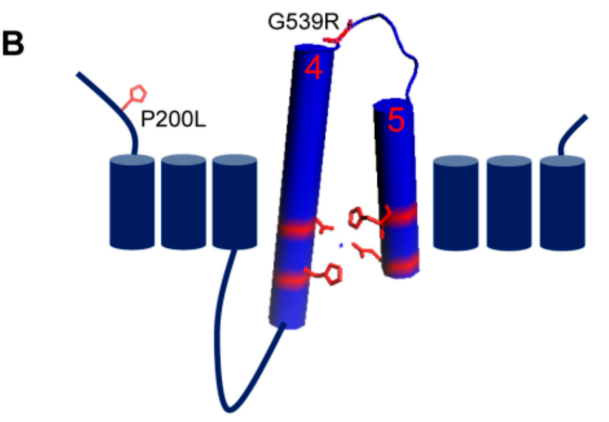

E

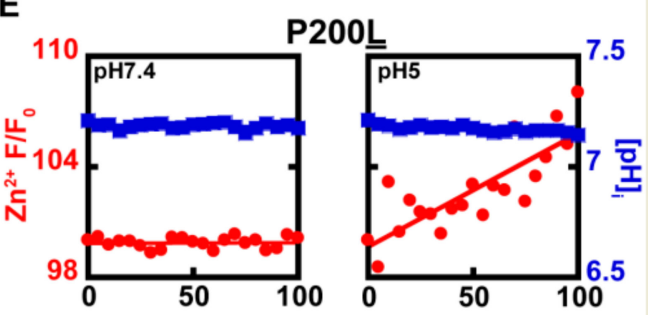

$\mathbf{F}$

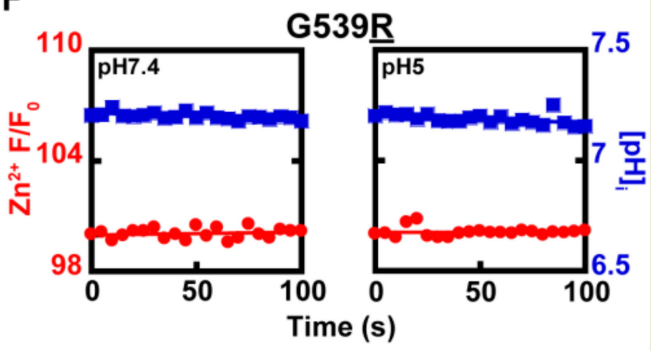

Figure 5. Genetic variations in ZIP4 affect catalytic and non-catalytic domains. (A) Immunoblot analysis of Acrodermatitis enteropathica (AE)-associated ZIP4 constructs, as indicated, from HEK293-T cell lysates. (B) Membrane orientation of ZIP4 illustrates the position of AE-associated variants P200L and G539R. (C) Normalized rates of $\mathrm{Zn}^{2+}$ uptake at pH7.4 (bottom panel-striped) and pH5 (top panel-filled), mediated by AE-associated ZIP4 mutants, in HEK293-T cells loaded with Fluozin-3AM $N \geq 5$. (D) Normalized rates of $\mathrm{H}^{+}$uptake at $\mathrm{pH} 7.4$ (bottom panel-striped) and $\mathrm{pH} 5$ (top panel-filled), mediated by AE-associated ZIP4 mutants, in HEK293-T cells loaded with BCECF-AM. (E-F) Representative traces of $\mathrm{Zn}^{2+}$ (red) and $\mathrm{H}+$ uptake (blue) recorded in HEK293-T cells transfected with ZIP4 ${ }^{\mathrm{P} 200 \mathrm{~L}}(\mathbf{E})$ and ZIP4 ${ }^{\mathrm{G} 539 \mathrm{R}}(\mathbf{F}) n \geq 3$. In (C) and (D), \# is $p \leq 0.05$ between cells expressing ZIP4 and G539R mutant at $\mathrm{pH} 5$.

\section{Discussion}

\subsection{ZIP4 Mediates $\mathrm{H}^{+} / \mathrm{Zn}^{+}$Co-Transport}

ZIP4 is a membrane embedded protein, enriched in enterocytes, where it mediates $\mathrm{Zn}^{2+}$ uptake. Previous work has shown a regulatory process in which ZIP4 undergoes rapid endocytosis following the addition of extracellular $\mathrm{Zn}^{2+}[23,24]$, thus constituting a major challenge in focusing directly on the transport mechanism of ZIP4. To overcome this difficulty, we monitored the timing of ZIP4 removal from the membrane using a HA tagged ZIP4. Tagging may potentially modulate ZIP4 surface expression or activity, however previous studies suggest that its expression pattern and activity are preserved [23]. Endocytosis only begins $2 \mathrm{~min}$ following $\mathrm{Zn}^{2+}$ exposure. Using live cell imaging, we monitored direct ion transport by ZIP4 during this time thereby addressing the concern that ZIP4 surface expression is changing while its activity is assayed. Notably fluorescence analysis used in this study to monitor $\mathrm{Zn}^{2+}$ does not provide an exact measure of transport but of the rate of ion accumulation within the cell. Alternative methods such as inductively coupled plasma mass spectrometry ICP-MS may provide a better quantitative measure for transport rates. Indeed, we have previously used 
ICP-MS measurements to corroborate the transport mediated by the Yiip transporter [21]. These studies were however carried out on a purified reconstituted Yiip, it is less likely that even overexpression of ZIP4 in HEK293-T cells is sufficiently strong to evoke a zinc signal that can be detected by ICP-MS.

The mechanism by which ZIPs transport $\mathrm{Zn}^{2+}$ is by and large unclear. Studies of mammalian ZIPs [34-36] have suggested an $\mathrm{HCO}^{-}$dependent co-transport mechanism, with increased rates of transport either at alkaline $\mathrm{pH}$ or following the addition of $\mathrm{HCO}^{-}$. Other studies on the bacterial ZIP homologue, ZIPB [39] indicated that it acts as a pH regulated, electrogenic facilitated diffusion channel, while studies on the puffer fish ZIP homologue, FrZIP2, indicated $\mathrm{H}^{+} / \mathrm{Zn}^{2+}$ co-transport. Our data does not support the involvement of $\mathrm{HCO}^{-}$. The addition of $\mathrm{HCO}^{-}$did not lead to elevated rates of $\mathrm{Zn}^{2+}$ transport, as previously reported also for FrZIP2 [37], and ZIPB [39].

Our results indicate that $\mathrm{Zn}^{2+}$ transport by mammalian $\mathrm{ZIP} 4$ is mediated by $\mathrm{Zn}^{2+} / \mathrm{H}^{+}$co-transport, based on the following findings: (1) extracellular acidification triggered ZIP4 dependent $\mathrm{Zn}^{2+}$ uptake. (2) In contrast, intracellular acidification-while extracellular $\mathrm{pH}$ was kept neutral, inhibited ZIP4 dependent $\mathrm{Zn}^{2+}$ uptake. (3) ZIP4 dependent $\mathrm{Zn}^{2+}$ uptake, triggered by extracellular acidification, is linked to ZIP4 dependent intracellular acidification. These findings strongly suggest that ZIP4 functions as an $\mathrm{H}^{+} / \mathrm{Zn}^{2+}$ co- transporter.

We suggest that the mammalian ZIP4 transporter underwent an evolutionary progression from the bacterial transporter that acts as a facilitated diffusion channel to an $\mathrm{H}^{+}$coupled $\mathrm{Zn}^{2+}$ transporter. What is the physiological advantage of $\mathrm{H}^{+} / \mathrm{Zn}^{2+}$ co-transport as opposed to transport facilitated via diffusion? Facilitated diffusion mediators support transport that is driven by the substrate gradient and allow fast charge movements across the plasma membrane. Indeed, in bacteria, free intracellular $\mathrm{Zn}^{2+}$ is vanishingly low [43] and such a mechanism would therefore be optimal for $\mathrm{Zn}^{2+}$ uptake. In mammalian cells, on the other hand, $\mathrm{Zn}^{2+}$ is an essential rate-limiting nutrient for eukaryotic cells, and $\mathrm{Zn}^{2+}$ deficiency is a frequent event with severe physiological consequences. Thus, pathways of $\mathrm{Zn}^{2+}$ uptake physiologically favor maximal efficient mechanisms, such as secondary active transport, rather than fast channel uptake systems.

Can an $\mathrm{H}^{+}$coupled transporter support greater $\mathrm{Zn}^{2+}$ uptake? Assuming a stoichiometry of $5 \mathrm{H}^{+}$ per $\mathrm{Zn}^{2+}$ (see Figure 2C) and based on the Gibbs free energy calculation (see materials and methods), the energy earned from $\mathrm{H}^{+}$transport at $\mathrm{pH} 7.4$ would be $-0.18674 \mathrm{Kcal} / \mathrm{mol}$, and $-17.318 \mathrm{Kcal} / \mathrm{mol}$, at $\mathrm{pH} 5$, thus yielding a $\mathrm{Zn}^{2+}$ gradient that is $10^{6}$-fold higher at $\mathrm{pH} 5$ than that at a neutral $\mathrm{pH}$. Luminal $\mathrm{pH}$, in the proximal small intestines is in the range of 5.5-7. Thus, our suggested mechanism of acidic $\mathrm{pH}$ regulation and $\mathrm{H}^{+}$coupled $\mathrm{Zn}^{2+}$ co-transport is also supported by the physiology of the gastrointestinal tract and would enable higher nutritional $\mathrm{Zn}^{2+}$ absorbance, by utilizing the driving force generated by the $\mathrm{H}^{+}$gradient. Correspondingly, the $\mathrm{pH}$ gradient across the plasma membrane of renal tubules would also enable coupling of $\mathrm{H}^{+}$and $\mathrm{Zn}^{2+}$, to enhance reabsorption of $\mathrm{Zn}^{2+}$. Indeed cells of the proximal tubule abundantly express ZIP4 [27], as well as other members of the ZIP family [44]. Notably, the highly acidic $\mathrm{pH}$ dependence of $\mathrm{Zn}^{2+}$ transport by ZIP4 differs from the predicted Pka value of the histidine residues at the $\mathrm{Zn}^{2+}$ transport site. It could however depend on the Glu/Asp residues at this site. Alternatively, this effect may be triggered allosterically by another site on the ZIP4.

Similar mechanisms of enhanced uptake via either $\mathrm{H}^{+}$or $\mathrm{Na}^{+}$coupling are well documented and abundant in the gastrointestinal tract [45] and renal tubules [46]. The $\mathrm{Na}^{+} /$Glucose co-transporter, for instance, couples glucose uptake to the $\mathrm{Na}^{+}$gradient across the plasma membrane to maximize glucose absorption from the intestinal lumen, and reabsorption from the proximal tubules of the nephron [47]. Indeed, in the proximal tubule of the nephron, reabsorption of filtered glucose reaches $100 \%$ efficiency. Interestingly, uptake of glucose from the blood stream into erythrocytes and muscle is mediated by facilitated diffusion that maintains constant basal levels of glucose within cells, per the available glucose gradient. Thus, the comparison of $\mathrm{Na}^{+} /$glucose co-transport and glucose-facilitated diffusion demonstrates in vivo the importance of an optimal mechanism for maximal absorption. Remarkably, like ZIP4, the renal $\mathrm{Na}^{+} /$glucose co-transporter SGLT1 has also been suggested to undergo 
a regulatory process of endocytosis [48], suggesting these diverse mechanisms did not only develop to support similar energy considerations, but also harbor similar regulatory strategies.

There are, however, risks related to a cellular toxic surge of $\mathrm{Zn}^{2+}[49,50]$ following a bolus of $\mathrm{Zn}^{2+}$ in the digestive system. This toxic ionic surge can be countered by several documented ZIP4 "safety valve mechanisms": (a) the slow rate of ZIP4 activity limits $\mathrm{Zn}^{2+}$ uptake and thus prevents potential toxicity, (b) the transporter undergoes rapid endocytosis $[23,24]$ that limits the duration of $\mathrm{Zn}^{2+}$ uptake, and (c) following uptake of $\mathrm{Zn}^{2+}$ from the digestive tract or renal tubules, $\mathrm{Zn}^{2+}$ can be rapidly transported, vectorially, into vesicular compartments by the activity of vesicular ZnTs [51] or across the plasma membrane via ZnT1 [52].

\subsection{Genetic Variants Associated with $\mathrm{Zn}^{2+}$ Deficiency in AE Patients Are Linked to Either Catalytic or Non-Catalytic Domains of ZIP4}

Genetic variation in ZIP4 is linked to $\mathrm{Zn}^{2+}$ deficiency in human subjects [26-29]. Several of these mutations lead to deletion and frame shift mutations, however, the majority result in single amino acid substitutions. Several of these lead to failure of ZIP4 accumulation at the plasma membrane, possibly due to misfolding that disrupts glycosylation sites and leads to failure in protein localization [29]. Two variants that were previously tested (P200L and G539R) differed from the rest, in that they did accumulate at the PM, yet showed diminished $\mathrm{Zn}^{2+}$ uptake over a 15-min time course assay [29].

Our results support the finding that overexpression of $\mathrm{ZIP} 4^{\mathrm{P} 200 \mathrm{~L}}$ enables its localization to the PM. However, in our shorter 2 min experiment, $\mathrm{Zn}^{2+}$ transport rates were no different from those of the wild type protein, indicating that catalytic $\mathrm{Zn}^{2+}$ transport was not impaired by this mutation. A possible explanation to the discrepancy in $\mathrm{Zn}^{2+}$ uptake measurements, could be that the P200 residue is found at the extracellular $\mathrm{N}$-terminal domain of ZIP4 that may be sensitive to changes in extracellular $\mathrm{Zn}^{2+}$ that regulate the transporter expression [53]. We proposed that this mutated transporter is catalytically active, but undergoes different regulation following $\mathrm{Zn}^{2+}$ exposure, which would explain the diminished uptake of $\mathrm{Zn}^{2+}$ measured during a 15 min experiment that allows endocytosis, but not observed after $2 \mathrm{~min}$. Thus, the apparent reduction in $\mathrm{Zn}^{2+}$ transport following the longer time-course may in fact be related to decreased availability of ZIP4 at the PM.

In the 15-min experiment, ZIP4 ${ }^{\mathrm{G} 539 \mathrm{R}}$ also showed diminished $\mathrm{Zn}^{2+}$ uptake [53]. However, this mutant also displayed aberration of $\mathrm{Zn}^{2+}$ transport in our $2 \mathrm{~min}$ transport assay. Interestingly, this residue is located at the loop connecting two transmembrane domains that are part of the putative catalytic domain of ZIP4. Hence, the substitution G539 to a positively charged arginine may directly modulate the catalytic ion transport core and could be attributed to disruption of either $\mathrm{Zn}^{2+}$ binding or the conformational change the transporter undergoes.

\section{Materials and Methods}

\subsection{Cell Cultures}

HEK293-T cells (human embryonic kidney cell line) were cultured in Dulbecco's modified Eagle's medium (DMEM), supplemented with 10\% fetal calf serum (FCS), $1 \%$ streptomycin and $1 \%$ penicillin. Cells were grown in either $25 \mathrm{~cm}^{2}$ or $75 \mathrm{~cm}^{2}$ flasks, in a humidified $\mathrm{CO}_{2}$ incubator, at $37^{\circ} \mathrm{C}$.

For live-cell imaging and immunocytochemistry experiments, cells were transferred on to glass cover slips, in $60 \mathrm{~mm}$ cell culture dishes. For immunoblotting, cells were transferred to $100-\mathrm{mm}$ cell culture dishes.

\subsection{Plasmid Transfection}

Cells were transfected with $0.67 \mu \mathrm{g}$ of the indicated HA tagged mZIP4 double-stranded plasmid (accession number BC023498, a kind gift from David Eide then in Kansas University [23]) using the well documented $\mathrm{CaPO}_{4}$ precipitation protocol in cultures of $40 \%-60 \%$ confluence, $48 \mathrm{~h}$ prior 
to experiment. The original paper [23] shows that the construct faithfully reached the cell plasma membrane and formed a functional transporter that was sensitive to $\mathrm{Zn}^{2+}$-dependent endocytosis. The various plasmids used for transfection are described in the following section. Cells transfected with an empty vector-pcDNA3.1—puromycin served as controls in all of the experiments.

Site-directed mutagenesis was performed using the QuikChange site-directed mutagenesis kit (Stratagene, San Diego, CA, USA) according to the following protocol (Tables 1 and 2).

Table 1. Site directed mutagenesis reaction components.

\begin{tabular}{cc}
\hline Component & Amount \\
\hline dsDNA template $(100 \mathrm{ng})$ & $0.333 \mu \mathrm{L}$ \\
\hline Primer $\mathrm{F}(0.3 \mu \mathrm{M})$ & $0.75 \mu \mathrm{L}$ \\
\hline Primer $\mathrm{R}(0.3 \mu \mathrm{M})$ & $0.75 \mu \mathrm{L}$ \\
\hline $\mathrm{dNTPs}$ & $1.5 \mu \mathrm{L}$ \\
\hline Enzyme & $0.5 \mu \mathrm{L}$ \\
\hline $\mathrm{ddH}_{2} 0$ (a total of $\left.25 \mu \mathrm{L}\right)$ & $21.167 \mu \mathrm{L}$ \\
\hline Total volume & $25 \mu \mathrm{L}$ \\
\hline
\end{tabular}

Table 2. Site directed mutagenesis PCR.

\begin{tabular}{cccc}
\hline Cycles & Step & Temperature & Time (min:s) \\
\hline \multirow{2}{*}{1} & $\begin{array}{c}\text { Initial } \\
\text { denaturation }\end{array}$ & $95^{\circ} \mathrm{C}$ & $5: 00$ \\
\hline \multirow{2}{*}{20} & Denaturation & $98^{\circ} \mathrm{C}$ & $0: 20$ \\
\cline { 2 - 4 } & Annealing & $78{ }^{\circ} \mathrm{C}$ & $0: 20$ \\
\hline \multirow{2}{*}{1} & Elongation & $72^{\circ} \mathrm{C}$ & $\begin{array}{c}0: 30 / 1 \mathrm{~kb} \\
\text { template }\end{array}$ \\
\hline
\end{tabular}

The following primers were designed using the primer design tool, on the University of Washington server (http://depts.washington.edu/bakerpg/webtools/PD.html) and manufactured by SIGMA (St. Louis, MO, USA).

ZIP4 ${ }^{\text {P200L: }}$ CCAAGGCCTGCTTAGCCCTCAGTA.

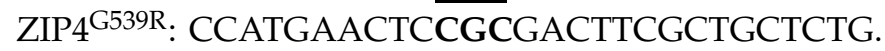

\subsection{Immunoblot Analysis}

Cells were extracted using $200 \mu \mathrm{L}$ of boiling denaturative lysis buffer (1\% SDS, $10 \mathrm{mM}$ Tris- $\mathrm{HCl}$, $\mathrm{pH}$ 8)/100-mm plate and transferred to ice. A protease inhibitor mixture (Boehringer Complete protease inhibitor mixture; Roche Applied Science) was added to the lysates, and protein concentrations were determined using the modified Lowry procedure [54]. SDS-PAGE and immunoblot analyses were performed, using anti-actin and anti-HA antibodies at dilutions of 1:40,000, and 1:2000 respectively. Secondary anti-mouse and anti-rabbit antibodies (Jackson Immunoesearch, West Grove, PA, USA) were used at dilutions of 1:20,000 and 1:40,000, respectively. Densitometry analysis of expression level was performed using EZQuant-Gel software (EZQuant, Hertzliya Pituach, Israel) as previously described [55].

The detection of membrane embedded ZIP4 the protocol described by Kim et al. [23] was used. Cells overexpressed mZIP4 tagged at its c-terminal with a HA tag facing the extracellular side. Cells

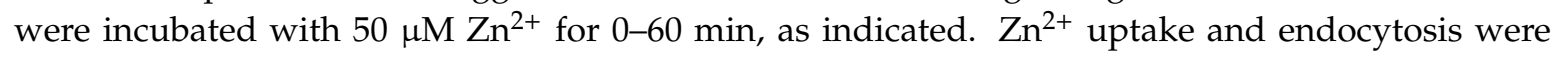


terminated by transferring the cells to ice and subsequently washing the cells with ice-cold PBS. Following this step, cells were fixed using 4\% PFA in 0.1 M PBS, without permeabilization of the cells. The HA tag at the extracellular c-terminus of mZIP4 enables us to label only the cell surface associated mZIP4. Cells were then washed in PBS to remove residual PFA, and following the removal of PBS, cells were incubated with $1 \mu \mathrm{g} / \mu \mathrm{L}$ anti-HA antibody, for $30 \mathrm{~min}$ at room temperature. The anti-HA antibody was recovered from the non-permeabilized intact cells and therefore marked the surface expression of mZIP4 using the previously demonstrated method [23]. Cells were then washed five times with PBS, to remove residual unbound antibodies and immediately exposed to boiling denaturative lysis buffer for western blotting. Following SDS-PAGE and immunoblotting, membranes were incubated with secondary anti-mouse antibody.

\subsection{Live Cell Fluorescent Imaging}

The imaging system consisted of an Axiovert 100 inverted microscope (Zeiss, Oberkochen, Germany), Polychrome II monochromator (TILL Photonics, Planegg, Germany), and a SensiCam cooled charge-coupled device (PCO, Kelheim, Germany). Fluorescent imaging measurements were acquired with the Imaging Workbench 6 software (Axon Instruments, Foster City, CA, USA) and analyzed using Microsoft Excel, Kaleidagraph and Matlab.

Cytoplasmic $\mathrm{Zn}^{2+}$ transport was determined in cells loaded with $1 \mu \mathrm{M}$ Fluozin-3AM. To verify that the fluorescence changes were related to intracellular ions, the cell-permeable heavy metal chelator $N, N, N^{\prime}, N^{\prime}$-tetrakis-(2-pyridylmethyl)-ethylenediamine (TPEN; $20 \mu \mathrm{M}$ ) was used.

Cytoplasmic $\mathrm{pH}$ changes, indicative of $\mathrm{H}^{+}$transport, were determined in cells loaded with $1 \mu \mathrm{M}$ BCECF-AM, a $\mathrm{pH}$ sensitive dye. Values of intracellular $\mathrm{pH}$ were calibrated using high $\mathrm{K}^{+}$Ringer's solution set to $\mathrm{pH}$ values of 6-8 in the presence of Nigericin [56].

Intracellular acidification was triggered using the ammonium prepulse paradigm [42]. Cells were superfused with Ringer's solution containing $\mathrm{NH} 4 \mathrm{Cl}(30 \mathrm{mM}$, replacing the equivalent $30 \mathrm{mM} \mathrm{NaCl})$, which was subsequently replaced with $\mathrm{NH} 4 \mathrm{Cl}$-free solution, thus triggering intracellular acidification.

\subsection{Statistics}

Data analysis was performed using the SPSS software (version 14.0; SPSS Inc., Chicago, IL, USA). All results shown are the means \pm S.E. of at least three individual experiments $(n \geq 3)$ in each several coverslips and several regions of interests (ROI) within coverslip were independently monitored and included in the analysis. Two tailed $t$-test $p$ values of $\leq 0.05$ were considered significant following Levene's test for equality of variances. Significance of the results \# is $p \leq 0.05$, between the indicated bars.

Author Contributions: E.H., I.S. and M.H. conceptualized the project, E.H. and M.L. provided the methodology, E.H. and M.L. performed formal analysis, E.H., I.S. and M.H. wrote the original draft, I.S. and M.H., supervised the study; I.S., recruited the funding for this project. All authors have read and agreed to the published version of the manuscript.

Funding: This study was supported by the DIP SE2372/1-1 and ISF 1429/17 to I.S.

Conflicts of Interest: The authors declare no conflict of interest

\section{References}

1. Vallee, B.L.; Falchuk, K.H. The biochemical basis of zinc physiology. Physiol. Rev. 1993, 73, 79-118. [CrossRef]

2. Prasad, A.S. Zinc deficiency. BMJ 2003, 326, 409-410. [CrossRef]

3. Andreini, C.; Banci, L.; Bertini, I.; Rosato, A. Counting the Zinc-Proteins Encoded in the Human Genome. J. Proteome Res. 2006, 5, 196-201. [CrossRef]

4. Eide, D.J. Zinc transporters and the cellular trafficking of zinc. Biochim. Biophys. Acta 2006, 1763, 711-722. [CrossRef]

5. Chimienti, F.; Devergnas, S.; Favier, A.; Seve, M. Identification and cloning of a beta-cell-specific zinc transporter, ZnT-8, localized into insulin secretory granules. Diabetes 2004, 53, 2330-2337. [CrossRef] 
6. Chimienti, F.; Devergnas, S.; Pattou, F.; Schuit, F.; Garcia-Cuenca, R.; Vandewalle, B.; Kerr-Conte, J.; Lommel, L.V.; Grunwald, D.; Favier, A.; et al. In vivo expression and functional characterization of the zinc transporter ZnT8 in glucose-induced insulin secretion. J. Cell Sci. 2006, 119, 4199-4206. [CrossRef]

7. Suzuki, T.; Ishihara, K.; Migaki, H.; Ishihara, K.; Nagao, M.; Yamaguchi-Iwai, Y.; Kambe, T. Two different zinc transport complexes of cation diffusion facilitator proteins localized in the secretory pathway operate to activate alkaline phosphatases in vertebrate cells. J. Biol. Chem. 2005, 280, 30956-30962. [CrossRef]

8. Suzuki, T.; Ishihara, K.; Migaki, H.; Matsuura, W.; Kohda, A.; Okumura, K.; Nagao, M.; Yamaguchi-Iwai, Y.; Kambe, T. Zinc transporters, ZnT5 and ZnT7, are required for the activation of alkaline phosphatases, zinc-requiring enzymes that are glycosylphosphatidylinositol-anchored to the cytoplasmic membrane. J. Biol. Chem. 2005, 280, 637-643. [CrossRef]

9. Ohana, E.; Hoch, E.; Keasar, C.; Kambe, T.; Yifrach, O.; Hershfinkel, M.; Sekler, I. Identification of the Zn2+ binding site and mode of operation of a mammalian Zn2+ transporter. J. Biol. Chem. 2009, 284, 17677-17686. [CrossRef]

10. Kawachi, M.; Kobae, Y.; Mimura, T.; Maeshima, M. Deletion of a Histidine-rich Loop of AtMTP1, a Vacuolar Zn2+/H+ Antiporter of Arabidopsis thaliana, Stimulates the Transport Activity. J. Biol. Chem. 2008, 283, 8374-8383. [CrossRef]

11. Chao, Y.; Fu, D. Kinetic study of the antiport mechanism of an Escherichia coli zinc transporter, ZitB. J. Biol. Chem. 2004, 279, 12043-12050. [CrossRef] [PubMed]

12. Lu, M.; Fu, D. Structure of the zinc transporter YiiP. Science 2007, 317, 1746-1748. [CrossRef] [PubMed]

13. Jeong, J.; Walker, J.M.; Wang, F.; Park, J.G.; Palmer, A.E.; Giunta, C.; Rohrbach, M.; Steinmann, B.; Eide, D.J. Promotion of vesicular zinc efflux by ZIP13 and its implications for spondylocheiro dysplastic Ehlers-Danlos syndrome. Proc. Natl. Acad. Sci. USA 2012, 109, E3530-E3538. [CrossRef] [PubMed]

14. Giunta, C.; Elçioglu, N.H.; Albrecht, B.; Eich, G.; Chambaz, C.; Janecke, A.R.; Yeowell, H.; Weis, M.; Eyre, D.R.; Kraenzlin, M.; et al. Spondylocheiro dysplastic form of the Ehlers-Danlos syndrome-An autosomal-recessive entity caused by mutations in the zinc transporter gene SLC39A13. Am. J. Hum. Genet. 2008, 82, 1290-1305. [CrossRef] [PubMed]

15. Fukada, T.; Civic, N.; Furuichi, T.; Shimoda, S.; Mishima, K.; Higashiyama, H.; Idaira, Y.; Asada, Y.; Kitamura, H.; Yamasaki, S.; et al. The zinc transporter SLC39A13/ZIP13 is required for connective tissue development; its involvement in BMP/TGF-beta signaling pathways. PLoS ONE 2008, 3, e3642. [CrossRef]

16. Dalton, T.P.; He, L.; Wang, B.; Miller, M.L.; Jin, L.; Stringer, K.F.; Chang, X.; Baxter, C.S.; Nebert, D.W. Identification of mouse SLC39A8 as the transporter responsible for cadmium-induced toxicity in the testis. Proc. Natl. Acad. Sci. USA 2005, 102, 3401-3406. [CrossRef]

17. Gitan, R.S.; Shababi, M.; Kramer, M.; Eide, D.J. A cytosolic domain of the yeast Zrt1 zinc transporter is required for its post-translational inactivation in response to zinc and cadmium. J. Biol. Chem. 2003, 278, 39558-39564. [CrossRef]

18. Taylor, K.M.; Nicholson, R.I. The LZT proteins; the LIV-1 subfamily of zinc transporters. Biochim. Biophys. Acta 2003, 1611, 16-30. [CrossRef]

19. Antala, S.; Ovchinnikov, S.; Kamisetty, H.; Baker, D.; Dempski, R.E. Computation and Functional Studies Provide a Model for the Structure of the Zinc Transporter hZIP4. J. Biol. Chem. 2015, 290, 17796-17805. [CrossRef]

20. Rogers, E.E.; Eide, D.J.; Guerinot, M.L. Altered selectivity in an Arabidopsis metal transporter. Proc. Natl. Acad. Sci. USA 2000, 97, 12356-12360. [CrossRef]

21. Hoch, E.; Lin, W.; Chai, J.; Hershfinkel, M.; Fu, D.; Sekler, I. Histidine pairing at the metal transport site of mammalian ZnT transporters controls Zn2+ over Cd2+ selectivity. Proc. Natl. Acad. Sci. USA 2012, 109, 7202-7207. [CrossRef] [PubMed]

22. Dufner-Beattie, J.; Wang, F.; Kuo, Y.-M.; Gitschier, J.; Eide, D.; Andrews, G.K. The acrodermatitis enteropathica gene ZIP4 encodes a tissue-specific, zinc-regulated zinc transporter in mice. J. Biol. Chem. 2003, 278, 33474-33481. [CrossRef] [PubMed]

23. Kim, B.-E.; Wang, F.; Dufner-Beattie, J.; Andrews, G.K.; Eide, D.J.; Petris, M.J. Zn2+-stimulated endocytosis of the mZIP4 zinc transporter regulates its location at the plasma membrane. J. Biol. Chem. 2004, 279, 4523-4530. [CrossRef] [PubMed] 
24. Weaver, B.P.; Dufner-Beattie, J.; Kambe, T.; Andrews, G.K. Novel zinc-responsive post-transcriptional mechanisms reciprocally regulate expression of the mouse Slc39a4 and Slc39a5 zinc transporters (Zip4 and Zip5). Biol. Chem. 2007, 388, 1301-1312. [CrossRef]

25. Dufner-Beattie, J.; Kuo, Y.-M.; Gitschier, J.; Andrews, G.K. The adaptive response to dietary zinc in mice involves the differential cellular localization and zinc regulation of the zinc transporters ZIP4 and ZIP5. J. Biol. Chem. 2004, 279, 49082-49090. [CrossRef]

26. Küry, S.; Dréno, B.; Bézieau, S.; Giraudet, S.; Kharfi, M.; Kamoun, R.; Moisan, J.-P. Identification of SLC39A4, a gene involved in acrodermatitis enteropathica. Nat. Genet. 2002, 31, 239-240. [CrossRef]

27. Wang, K.; Zhou, B.; Kuo, Y.-M.; Zemansky, J.; Gitschier, J. A novel member of a zinc transporter family is defective in acrodermatitis enteropathica. Am. J. Hum. Genet. 2002, 71, 66-73. [CrossRef]

28. Nakano, A.; Nakano, H.; Nomura, K.; Toyomaki, Y.; Hanada, K. Novel SLC39A4 mutations in acrodermatitis enteropathica. J. Invest. Dermatol. 2003, 120, 963-966. [CrossRef]

29. Wang, F.; Kim, B.-E.; Dufner-Beattie, J.; Petris, M.J.; Andrews, G.; Eide, D.J. Acrodermatitis enteropathica mutations affect transport activity, localization and zinc-responsive trafficking of the mouse ZIP4 zinc transporter. Hum. Mol. Genet. 2004, 13, 563-571. [CrossRef]

30. Prasad, A.S. The role of zinc in gastrointestinal and liver disease. Clin. Gastroenterol. 1983, 12, 713-741.

31. Zhang, T.; Liu, J.; Fellner, M.; Zhang, C.; Sui, D.; Hu, J. Crystal structures of a ZIP zinc transporter reveal a binuclear metal center in the transport pathway. Sci. Adv. 2017, 3, e1700344. [CrossRef] [PubMed]

32. Li, M.; Zhang, Y.; Liu, Z.; Bharadwaj, U.; Wang, H.; Wang, X.; Zhang, S.; Liuzzi, J.P.; Chang, S.-M.; Cousins, R.J.; et al. Aberrant expression of zinc transporter ZIP4 (SLC39A4) significantly contributes to human pancreatic cancer pathogenesis and progression. Proc. Natl. Acad. Sci. USA 2007, 104, 18636-18641. [CrossRef] [PubMed]

33. Li, M.; Zhang, Y.; Bharadwaj, U.; Zhai, Q.J.; Ahern, C.H.; Fisher, W.E.; Brunicardi, F.C.; Logsdon, C.D.; Chen, C.; Yao, Q. Down-regulation of ZIP4 by RNA interference inhibits pancreatic cancer growth and increases the survival of nude mice with pancreatic cancer xenografts. Clin. Cancer Res. 2009, 15, 5993-6001. [CrossRef] [PubMed]

34. Gaither, L.A.; Eide, D.J. Functional expression of the human hZIP2 zinc transporter. J. Biol. Chem. 2000, 275, 5560-5564. [CrossRef] [PubMed]

35. He, L.; Girijashanker, K.; Dalton, T.P.; Reed, J.; Li, H.; Soleimani, M.; Nebert, D.W. ZIP8, member of the solute-carrier-39 (SLC39) metal-transporter family: Characterization of transporter properties. Mol. Pharmacol. 2006, 70, 171-180. [CrossRef] [PubMed]

36. Girijashanker, K.; He, L.; Soleimani, M.; Reed, J.M.; Li, H.; Liu, Z.; Wang, B.; Dalton, T.P.; Nebert, D.W. Slc39a14 gene encodes ZIP14, a metal/bicarbonate symporter: Similarities to the ZIP8 transporter. Mol. Pharmacol. 2008, 73, 1413-1423. [CrossRef]

37. Qiu, A.; Hogstrand, C. Functional expression of a low-affinity zinc uptake transporter (FrZIP2) from pufferfish (Takifugu rubripes) in MDCK cells. Biochem. J. 2005, 390, 777-786. [CrossRef]

38. Antala, S.; Dempski, R.E. The human ZIP4 transporter has two distinct binding affinities and mediates transport of multiple transition metals. Biochemistry 2012, 51, 963-973. [CrossRef]

39. Lin, W.; Chai, J.; Love, J.; Fu, D. Selective electrodiffusion of zinc ions in a Zrt-, Irt-like protein, ZIPB. J. Biol. Chem. 2010, 285, 39013-39020. [CrossRef]

40. Kiedrowski, L. Cytosolic acidification and intracellular zinc release in hippocampal neurons. J. Neurochem. 2012, 121, 438-450. [CrossRef]

41. Sensi, S.L.; Ton-That, D.; Sullivan, P.G.; Jonas, E.A.; Gee, K.R.; Kaczmarek, L.K.; Weiss, J.H. Modulation of mitochondrial function by endogenous Zn2+ pools. Proc. Natl. Acad. Sci. USA 2003, 100, 6157-6162. [CrossRef] [PubMed]

42. Azriel-Tamir, H.; Sharir, H.; Schwartz, B.; Hershfinkel, M. Extracellular Zinc Triggers ERK-dependent Activation of $\mathrm{Na}+\mathrm{H}+$ Exchange in Colonocytes Mediated by the Zinc-sensing Receptor. J. Biol. Chem. 2004, 279, 51804-51816. [CrossRef] [PubMed]

43. Outten, C.E.; O'Halloran, T.V. Femtomolar sensitivity of metalloregulatory proteins controlling zinc homeostasis. Science 2001, 292, 2488-2492. [CrossRef] [PubMed]

44. Wang, F.; Dufner-Beattie, J.; Kim, B.-E.; Petris, M.J.; Andrews, G.; Eide, D.J. Zinc-stimulated endocytosis controls activity of the mouse ZIP1 and ZIP3 zinc uptake transporters. J. Biol. Chem. 2004, 279, 24631-24639. [CrossRef] 
45. Thwaites, D.T.; Anderson, C.M.H. H+-coupled nutrient, micronutrient and drug transporters in the mammalian small intestine. Exp. Physiol. 2007, 92, 603-619.

46. Hummel, C.S.; Lu, C.; Loo, D.D.F.; Hirayama, B.A.; Voss, A.A.; Wright, E.M. Glucose transport by human renal Na+/D-glucose cotransporters SGLT1 and SGLT2. Am. J. Physiol. Cell Physiol. 2011, 300, C14-C21. [CrossRef]

47. Wright, E.M. Renal Na(+)-glucose cotransporters. Am. J. Physiol. Renal Physiol. 2001, 280, F10-F18. [CrossRef]

48. Wright, E.M.; Hirsch, J.R.; Loo, D.D.; Zampighi, G.A. Regulation of Na+/glucose cotransporters. J. Exp. Biol. 1997, 200, 287-293.

49. Choi, D.W.; Koh, J.Y. Zinc and brain injury. Annu. Rev. Neurosci. 1998, 21, 347-375. [CrossRef]

50. Weiss, J.H.; Sensi, S.L.; Koh, J.Y. Zn(2+): A novel ionic mediator of neural injury in brain disease. Trends Pharmacol. Sci. 2000, 21, 395-401. [CrossRef]

51. Kambe, T. Molecular architecture and function of ZnT transporters. Curr. Top. Membr. 2012, 69, $199-220$. [PubMed]

52. Qin, Y.; Thomas, D.; Fontaine, C.P.; Colvin, R.A. Silencing of ZnT1 reduces Zn2+ efflux in cultured cortical neurons. Neurosci. Lett. 2009, 450, 206-210. [CrossRef]

53. Kambe, T.; Andrews, G.K. Novel proteolytic processing of the ectodomain of the zinc transporter ZIP4 (SLC39A4) during zinc deficiency is inhibited by acrodermatitis enteropathica mutations. Mol. Cell. Biol. 2009, 29, 129-139. [CrossRef]

54. Markwell, M.A.; Haas, S.M.; Bieber, L.L.; Tolbert, N.E. A modification of the Lowry procedure to simplify protein determination in membrane and lipoprotein samples. Anal. Biochem. 1978, 87, 206-210. [CrossRef]

55. Ventura-Bixenshpaner, H.; Asraf, H.; Chakraborty, M.; Elkabets, M.; Sekler, I.; Taylor, K.M.; Hershfinkel, M. Enhanced ZnR/GPR39 Activity in Breast Cancer, an Alternative Trigger of Signaling Leading to Cell Growth. Sci. Rep. 2018, 8, 1-15. [CrossRef] [PubMed]

56. Machen, T.E.; Leigh, M.J.; Taylor, C.; Kimura, T.; Asano, S.; Moore, H.-P.H. pH of TGN and recycling endosomes of $\mathrm{H}+/ \mathrm{K}+-\mathrm{ATPase}-$ transfected HEK-293 cells: Implications for $\mathrm{pH}$ regulation in the secretory pathway. Am. J. Physiol. Cell Physiol. 2003, 285, C205-C214. [CrossRef] [PubMed]

(C) 2020 by the authors. Licensee MDPI, Basel, Switzerland. This article is an open access article distributed under the terms and conditions of the Creative Commons Attribution (CC BY) license (http://creativecommons.org/licenses/by/4.0/). 